\title{
KÜLFÖLDI HALLGATÓK ELÉGEDETTSÉGÉT ÉS LOJALITÁSÁT BEFOLYÁSOLÓ TÉNYEZŐK FELTÁRÁSA A SZEGEDI TUDOMÁNYEGYETEMEN - KIZÁRÓLAG AZ EGYETEMI TÉNYEZŐK SZÁMÍTANAK?
}

\section{FACTORS INFLUENCING FOREIGN STUDENT SATISFACTION AND LOYALTY AT THE UNIVERSITY OF SZEGED - ONLY UNIVERSITY-RELATED FACTORS COUNT?}

A nemzetköziesedés napjaink egyik leginkább kutatott felsőoktatási területévé vált, hiszen a növekvő külföldi hallgatói létszám arra készteti a magyar egyetemeket, hogy jobban megismerjék diákjaikat. Ezen okokból kifolyólag a jelen tanulmány célja, hogy feltárja, milyen tényezők befolyásolják a külföldi hallgatók elégedettségét és lojalitását a Szegedi Tudományegyetemen. A felállított elméleti modell PLS-SEM (parciális legkisebb négyzetek módszere - strukturális egyenletek modellje) elemzése azt fedte fel, hogy a kompetenciák és a tananyag tartalma befolyásolják az egyetemhez kapcsolódó elégedettséget, míg az ahhoz szorosan nem kapcsolódó elégedettségre a szegedi élet, a nemzetközi légkör és a szabadidős létesítmények hatnak. Érdekes eredmény, hogy az egyetemhez kapcsolódó és ahhoz nem kapcsolódó elégedettség is befolyásolja a külföldi hallgatók lojalitását. Az eredmények tehát alátámasztják azt a feltételezést, hogy a külföldi hallgatók elégedettségének és lojalitásának pontosabb megismerése okán az egyetemhez szorosan kapcsolódó, valamint ahhoz nem kapcsolódó tényezőket is vizsgálni szükséges.

Kulcsszavak: elvárások, elégedettség, lojalitás, felsőoktatás, PLS-SEM (partial least squares structural equation modelling, parciális legkisebb négyzetek módszere - strukturális egyenletek modellje)

Internationalization has been a widely researched topic in recent years. Higher education institutions developed a need to examine foreign student expectations, satisfaction, and loyalty, as there has been an upsurge in foreign student numbers. Therefore, the current paper aims to uncover what factors affect foreign student satisfaction and loyalty at the University of Szeged. Based on the PLS-SEM (partial least squares - structural equation modelling) analysis of the theoretical model, research results indicate that competences and content of the curriculum influence university-related satisfaction, while non-university-related satisfaction is affected by living in the city, international environment, and places to spend free time at. Both university- and non-university-related satisfaction have an effect on loyalty. The results confirm that in order to understand foreign student satisfaction and loyalty, aspects not strictly related to the university should also be studied, besides university-related factors.

Keywords: expectation, satisfaction, loyalty, higher education, PLS-SEM (partial least squares structural equation modelling)

\section{Funding/Finanszírozás:}

A szerző a tanulmány elkészítésével összefüggésben nem részesült pályázati vagy intézményi támogatásban. The author did not receive any grant or institutional support in relation with the preparation of the study.

\section{Szerző/Author:}

Dr. Kéri Anita, egyetemi adjunktus, Szegedi Tudományegyetem, (keri.anita@eco.u-szeged.hu)

A cikk beérkezett: 2021. 01. 03-án, javítva: 2021. 06. 06-án, elfogadva: 2021. 07. 07-én.

This article was received: 03. 01. 2021, revised: 06. 06. 2021, accepted: 07. 07. 2021.

\footnotetext{
$\mathrm{Az}$ elmúlt évek egyik legnagyobb horderejü felsőoktatási tendenciája a nemzetköziesedés és a mobilitás erősödése (Hrubos, 2017), hiszen az ösztöndíjprogramok széles skálája segíti a hallgatói mobilitást, mely alól
}

Magyarország sem kivétel, ugyanis a külföldi önköltséges hallgatók mellett egyre hangsúlyosabb a külföldi ösztöndíjas hallgatók aránya is. Az intézmények közötti, hallgatókért folytatott verseny fokozatosan éleződik, a verse- 
nyelőnyt pedig akár a hallgatókkal kialakult partnerségi viszony és az oktatók egyéni jólléte is erősíthet (Toarniczky et al., 2020; Tóth \& Bedzsula, 2021). Az egyetemek részéről továbbá megindult egy fejlődési folyamat, mely a nyugathoz való felzárkózást szorgalmazza (Sebrek, 2020).

Az említett tendenciáknak köszönhetően a felsőoktatás szereplőinek vizsgálata napjainkra igencsak elterjedt hazánkban is, hiszen intézményi imázst, az oktatás megítélését, elégedettséget (Malota, 2010; Berács et al., 2014), oktatási minőséget (Hetesi \& Kürtösi, 2011), minőségbiztosítást (Surman \& Szabó, 2020), újraválasztást, ösztöndíjprogrammal való elégedettséget (Kasza \& Hangyál, 2018), intézményválasztási szempontokat (Molnár et al., 2017; Kömíves, 2020), gazdasági hatást (Császár \& Alpek, 2018), motivációt, kulturális ismeretet és szájreklámot (Mucsi et al., 2019; Mucsi et al., 2020) is kutatnak a szakértők.

Ám a törekvések túlnyomó többsége nem kimondottan a külföldi hallgatókat, hanem a hallgatók adott intézményhez való viszonyát vizsgálja (Császár \& Wusching, 2014; Savitha \& Padmaja, 2017), és a kutatások többségében szó sem esik a nem szorosan egyetemhez köthető, ám szintén kulcsfontosságúnak tekinthető tényezőkről, mint például a lakhatás vagy életminőség (Malota, 2016; Kéri et al., 2018). A külföldi tanulási folyamat egészének vizsgálatával azonban olyan információkat és hallgatói elégedettséget, valamint lojalitást befolyásoló tényezőket tárhatunk fel, melyek új megvilágításban segíthetnének értelmezni a hallgatók külföldi tanulási folyamatát.

Jelen tanulmány célja, hogy a Szegedi Tudományegyetem példáján keresztül megvizsgálja, hogy milyen egyetemi és nem egyetemi tényezők befolyásolják a külföldi hallgatók elégedettségét és lojalitását, továbbá célul tűzi ki a külföldi hallgatói lojalitás mélyebb megismerését. A szakirodalmi feltárás és előzetes primer kutatás eredményei alapján felállított elméleti modell vizsgálja a külföldi hallgatók elégedettségét és lojalitását befolyásoló tényezőket a kiválasztott egyetemen.

A tanulmány újszerüségét az adja, hogy az egyetemhez füződő tényezőkön felül a külföldi hallgatók nem egyetemmel kapcsolatos elégedettségét és lojalitását is vizsgálat alá vonja, továbbá meghatározza az elvárások, elégedettség és lojalitás felsőoktatásban, külföldi hallgatókra értelmezhető definícióját. A tanulmány módszertanilag komplex módon vizsgálja a külföldi hallgatókat, hiszen szekunder és korábbi primer kutatásokon alapuló elméleti modellt állít fel és vizsgál meg online kérdőíves megkérdezés, PLS-útelemzés, faktor- és klaszterelemzés segítségével. Jelen tanulmányban kizárólag a felállított modell és annak eredményei jelennek meg, az ezt megelöző korábbi primer kutatások bemutatására nem kerül sor.

A tanulmány hat fó részből áll. A bevezetés után a második fejezet az elvárások, elégedettség és lojalitás kutatásban alkalmazott definícióit tekinti át, a harmadik fejezet pedig a hipotéziseket és az elméleti modellt hivatott bemutatni. A negyedik fejezet a kutatás módszertanát, az ötödik pedig annak eredményeit szemlélteti. A hatodik és egyben utolsó fejezet összegzi a kutatási eredményeket és korlátokat, valamint jövőbeli kutatási irányokat jelöl ki.

\section{Szakirodalmi áttekintés}

Ebben a fejezetben a kutatási célhoz kapcsolódó fogalmakat és felsőoktatásban használatos definíciójukat tekintjük át és határozzuk meg. A bemutatott főbb témakörök az elvárások, az elégedettség és a lojalitás, melyek definiálása kimondottan külföldi hallgatókra vonatkozik. A tanulmány azokat a diákokat tekinti külföldi hallgatóknak, akik nem határmenti országból (Ausztria, Horvátország, Románia, Szerbia, Szlovákia, Szlovénia, Ukrajna) érkeztek Magyarországra tanulni, melynek fö oka az, hogy ezekből az országokból érkezők többnyire anyanyelvként beszélik a magyart és kettős állampolgársággal rendelkeznek, tehát második hazájukba érkeznek továbbtanulni.

Annak érdekében, hogy mélyebben is betekintést nyerhessünk a vizsgált fogalmakba és összefüggéseikbe, először azok pontos meghatározására van szükség. A szakirodalomban az elvárásokat többnyire az elégedettséggel együtt vizsgálják, és úgy definiálják azt, mint befolyásoló tényező (Cardozo, 1965), szubjektív összehasonlítási alap (Oliver, 1999), előrejelző tényező (Churchill \& Suprenant, 1982), vagy a korábbi tapasztalat eredménye (Woodruff, 1983). A felsőoktatási szakirodalomban leginkább Oliver diszkonfirmációs teóriája alapján definiálják az elvárásokat (Oliver, 1999; Chui et al., 2016), melyek vonatkozhatnak egyetemhez kötődő, és ahhoz szorosan nem kötődő tényezőkre is (Byrne \& Flood, 2005; Bryla, 2015), habár nem tesznek egyértelmü különbséget e két kategória között. Jelen tanulmányban a külföldi hallgatók elvárásai alatt azokat az egyetemmel kapcsolatos és egyetemhez nem szorosan kapcsolódó felidézett várakozásokat értjük, melyeket a hallgatók a külföldön való tanulási folyamattal szemben támasztanak és melyek a külföldi egyetemen tanulás teljes időtartamára vonatkoznak.

Annak ellenére, hogy a fogyasztói elégedettség széles körben tanulmányozott fogalom a szakirodalomban, nincs konszenzus annak pontos meghatározásáról, és többnyire úgy definiálják, mint az elvárások és tapasztalatok szubjektív összehasonlítása (Churchill \& Suprenant, 1982; Oliver, 1999; Elkhani \& Bakri, 2012). A felsőoktatási szakirodalom feltárja, hogy a külföldi diákok elégedettségét számos tényező befolyásolhatja, azonban ezeket a faktorokat nem mindig különböztetik meg egymástól egyértelműen. A témában íródott kutatások elhanyagolható része fókuszál csupán azokra a tényezőkre, melyekre az egyetemnek nincsen közvetlen hatása, ám befolyásolhatják a hallgatók elégedettségét (Schertzer \& Schertzer, 2004; Yang et al., 2013; Mihanovic et al., 2016; Machado et al., 2011), a tanulmányban ezek nem egyetemhez kapcsolódó tényezőkként jelennek meg. Az elégedettségkutatások többsége kimondottan az egyetemhez szorosan köthetö tényezőket vizsgálja (Alves \& Raposo, 2009; Giner \& Rillo, 2016), melyek úgy definiálhatók, hogy ezekre a tényezőkre az intézménynek közvetlen hatása van. Jelen kutatásban a külföldi hallgatók elégedettsége alatt az elvárások és tapasztalatok szubjektív összehasonlítása értendő, mely a hallgatók külföldön töltött tanulmányainak teljes folya- 
matára vonatkozik, és a fogyasztással egy időben, vagy az után értelmezhető mind az egyetemi, mind az egyetemhez szorosan nem köthető tényezőkre vonatkozóan.

Az elégedett fogyasztóból azonban nem mindig lesz lojális fogyasztó. A lojalitást kezdetben az elégedettséggel és vevőmegtartással azonos fogalomként határozták meg, később pedig azt állították, hogy a lojalitás újravásárlással mérhető (Reichheld et al., 2000). A lojalitás komplex megközelítése szerint az nem csupán újravásárlás, hanem elkötelezettség, érzelmi kötődés és esetleges továbbajánlás (Oliver, 1999; Reichheld, 2003). Jelen tanulmány a lojalitást az utóbbi megközelítés alapján vizsgálja és esetleges újravásárlás mellett pozitív attitűdként, elkötelezettségként és továbbajánlásként határozza meg, mely az egyetemi képzés ideje alatt és annak vége után is kitarthat.

A kutatásban alkalmazott definíciók áttekintése után az elméleti modell felállítása következik a külföldi hallgatók elégedettségét és lojalitását befolyásoló tényezők feltárása érdekében. A szakirodalom áttekintése alapján beszélhetünk kimondottan egyetemre vonatkozó és nem szorosan egyetemhez kapcsolódó elvárásokról is (Aldemir \& Gülcan, 2004; Byrne \& Flood, 2005; Byrne et al., 2012), melyből az a következtetés vonható le, hogy az elvárások e két tényező összességeként értelmezhetők.

Továbbá a felsőoktatás szakirodalmában számos kutatás foglalkozik ezen elvárások és az elégedettség közötti kapcsolat feltárásával, melyek közül sok tanulmány a SERVQUAL minőségkoncepciója alapján hasonlítja össze a hallgatói elvárásokat és a tapasztalatot (Yousapronpaiboon, 2014; Jager \& Gbadamosi, 2013; Chui et al., 2016), így meghatározva a hallgatók elégedettségét. Más vizsgálatokban fogyasztói indexekre alapozva kutatják a hallgatók elégedettségét, melyekben az elvárások, mint elégedettséget befolyásoló tényezők vannak jelen (Eurico et al., 2015; Shahsavar \& Sudzina, 2017). Jelen tanulmányban a hallgatók külföldi tanulási folyamatának egyik lépéseként jelennek meg az elvárások, melyet az elégedettség követ, és mely lépések között kapcsolat feltételezhető. E következtetés és a szakirodalmi feltárás alapján az alábbi hipotézisek állíthatók fel:

H1: Az elvárások hatással vannak az egyetemmel kapcsolatos elégedettségre.

H2: Az elvárások befolyásolják az egyetemen kívüli tényezőkkel kapcsolatos elégedettséget.

Ami az elégedettséget illeti, a szakirodalomban mindkét (egyetemhez köthető és egyetemhez nem szorosan köthetö) aspektusra találunk példát (Alves \& Raposo, 2009; Mekic \& Mekic, 2016), ám ennek ellenére ezek elkülönítése, kategorizálása nehézkes, vagy egyáltalán nem valósul meg. Az egyetemmel kapcsolatos elégedettségmérések legtöbbször a szolgáltatás minőségének elemeit kutatják saját maguk által meghatározott dimenziók mellett (Lee, 2010; El-Hilali et al., 2015; Cardona \& Bravo, 2012; Owlia \& Aspinwall, 1996; Lenton, 2015; Elliot \& Healy, 2001). Elliot és Healy (2001) tizenegy dimenzió mentén mérték a hallgatói elégedettséget, mely dimenziók a felsőoktatás hatékonysága, az egyetemi légkör, az egyetemi élet, az egyetemi kisegítő szervezetek, az egyén támogatása, hatékonyság, pénzügyi segélyezési hatékonyság, beiratkozásnál történő hatékonyság, biztonságérzet, szolgáltatási kiválóság és hallgatóközpontúság voltak. Lee (2010) szintén a minőséggel való elégedettséget kutatta, és arra a következtetésre jutott, hogy ez származási ország szerint változhat. Míg El-Hilali és szerzőtársai (2015) három dimenziót vizsgáltak, az egyetem imázsát, a felsőoktatási programot és a tanítási módszereket, addig Lenton (2015) az oktatást, a hallgatók felméréseit, a hallgatóknak nyújtott visszajelzéseket, a hallgatók intézményi támogatását, a szervezetet, az erőforrásokat és a személyes fejlődést vizsgálta. Cardona és Bravo (2012) kutatásukban olyan modellt alkalmaztak, melyben az oktatás és az oktatási folyamat, az infrastruktúra, a hallgatók és oktatók/adminisztratív dolgozók közötti interakció és kommunikáció, és a légkör minőségét vizsgálták. Az egyik talán legátfogóbb kutatást Owlia és Aspinwall (1996) hajtotta végre, akik a felsőoktatással való elégedettségnek hat különböző minőségi dimenzióját elemezték: a megfogható elemeket (felszereltség és létesítmények), a kompetenciát (oktatói szakértelem, teoretikus és gyakorlatias tudás), hallgatók szükségleteinek megértésével kapcsolatos attitüdöt, a tananyag tartalmát, a tananyag átadását (hatékony prezentációt és visszacsatolás nyújtását) és a megbízhatóságot.

A fenti források alapján jól látható, hogy nincsen egységesség az egyetemhez kapcsolódó elégedettséget befolyásoló tényezők értelmezésében és csoportosításában sem, így a szakirodalmi áttekintés és a korábbi primer kutatások alapján átfogó dimenziók határozhatók meg, mint egyetemmel kapcsolatos elégedettséget befolyásoló vizsgálandó tényezők: tárgyi eszközök, oktatói kompetenciák, tananyag tartalma, attitűd, megbízhatóság és tananyag átadásának módja. Ezek alapján az a vizsgálandó hipotézisek:

H3a: A tárgyi eszközökkel való elégedettség pozitív hatást fejt ki az egyetemmel való elégedettségre.

H3b: Az oktatói kompetenciák pozitív hatással vannak az egyetemmel való elégedettségre.

H3c: Az órai tananyag tartalma pozitívan hat az egyetemmel való elégedettségre.

H3d: Az oktatók és adminisztratív dolgozók attitüdje pozitív hatással van az egyetemmel való elégedettségre.

H3e: Az oktatók és adminisztratív dolgozók megbízhatósága pozitívan befolyásolja az egyetemmel való elégedettséget.

H3f: A tananyag átadásának módszere pozitív hatással van az egyetemmel való elégedettségre.

A következőkben a nem egyetemmel kapcsolatos elégedettségre ható tényezők csoportosítása következik. A szakirodalomban kevés olyan kutatás lelhető fel, mely részben vagy kimondottan a külföldi hallgatók elégedettsége kapcsán, az egyetemen kívüli tényezők feltárására koncentrál (Schertzer \& Schertzer, 2004; Yang et al., 2013; Mihanovic et al., 2016; Machado et al., 2011), valamint e tanulmányokban szereplő tényezők gyakran szorosan kapcsolódnak a tantermi tényezőkhöz (Yang et 
al., 2013). Gregg (1972) tartozott az első olyan kutatók közé, aki felismerte, hogy az egyetemen kívüli tényezők is nagyban hozzájárulnak a hallgatók elégedettségéhez, Evans (1972) pedig kijelentette, hogy a társasági élet, az életszínvonal és a légkör is befolyásolja az elégedettséget. Ezekben a kutatásokban fény derül az egyetemen kívüli tényezők fontosságára, és arra is, hogy a hallgatók elégedettsége a tantermen kívüli tényezőktől is nagy mértékben függ, mint például a megélhetési költségek, a munkalehetőségek (Schertzer \& Schertzer, 2004), a személyes és társasági élet, a lakóhely, a szórakozási és szabadidős tevékenységek (Billups, 2008; Mihanovic et al., 2016), a város és a város nemzetközi légköre (Machado et al., 2011), a kulturális és sportolási lehetőségek, vagy akár a középületek nyitvatartási ideje (Aldemir \& Gülcan, 2004). A szakirodalmi áttekintés mellett korábbi kvalitatív kutatások is igazolták, hogy számos olyan tényező befolyásolhatja a külföldi hallgatók elégedettségét, melyekre az intézménynek nincsen közvetlen hatása (Kéri, 2019). A tényezőket áttekintve egy átfogó csoportosítás hozható létre, melyek alapján további vizsgálatot igényelnek az életkörülmények, (nemzetközi) légkör, középületek és közterek, szabadidős létesítmények és munkalehetőségek egyetemen kívüli elégedettségre gyakorolt hatásai. Ezen indoklás okán az alábbi hipotézisek fogalmazhatók meg:

H4a: A szegedi élet hatással van az egyetemen kívüli tényezőkkel kapcsolatos elégedettségre.

H4b: Az egyetemen kívüli nemzetközi légkör hatással van az egyetemen kívüli tényezőkkel kapcsolatos elégedettségre.

H4c: A középületek és közterek elérhetősége befolyásolja az egyetemen kívüli tényezőkkel való elégedettséget.

H4d: A szabadidő eltöltésére alkalmas létesítmények hatással vannak az egyetemen kívüli tényezőkkel való elégedettségre.

H4e: A munkavállalási lehetőségek befolyásolják az egyetemen kívüli tényezőkkel való elégedettséget.

A kutatók az egyetemmel kapcsolatos elégedettség fő kiemelkedő tényezői és lojalitást befolyásoló tényezők között tartják számon a szakok elérhetőségét, a felsőoktatási intézmény elhelyezkedését, nagyságát, komplexitását, az oktatás minőségét (Huybers et al., 2015), az oktatóktól kapott visszacsatolásokat és a velük való kommunikációt (Jager \& Gbadamosi, 2013), a megfelelő tanulmányi ütemtervet, a hallgatókat támogató létesítményeket, fizikai környezetet és felszereltséget (Wiers-Jenssen et al., 2002). Ezek alapján az feltételezhető, hogy az egyetemhez szorosan kötődő tényezőkkel való elégedettség befolyással van a külföldi hallgatók lojalitására.

H5: Az egyetemmel való elégedettség pozitívan hat a lojalitásra.

Számos tanulmány igazolta tehát az összefüggést a külföldi hallgatók elégedettsége és lojalitása között (Alves \& Raposo, 2009; Elliot \& Healy, 2001; Wiers-Jenssen et al., 2002; Lenton, 2015; Cardona \& Bravo, 2012; Owlia \&
Aspinwall, 1996; El-Hilali et al., 2015; Lee, 2010; Schertzer \& Schertzer, 2004; Giner \& Rillo, 2016). Ám azokban a kutatásokban, melyekben részben vagy kizárólag az iskolán kívüli tényezőkkel kapcsolatos elégedettségre is fókuszálnak, nem terjedt el széles körben e tényezők lojalitásra való hatásának vizsgálata (Schertzer \& Schertzer, 2004; Yang et al., 2013; Mihanovic et al., 2016; Machado et al., 2011). A fentiek alapján az feltételezhető, hogy az egyetemen kívüli tényezőkkel való elégedettség is pozitívan hathat a külföldi hallgatók lojalitására.

H6: Az egyetemen kívüli tényezőkkel való elégedettség pozitív hatással van a lojalitásra.

A kvantitatív kutatásban felvázolt hipotéziseket az 1. ábra szemlélteti, melyen látható, hogy az elvárások egyetemi és egyetemen kívüli tényezőkkel kapcsolatos elégedettségre való hatása, valamint ez utóbbi két tényező lojalitásra való hatása vizsgálandó. A harmadik és negyedik alhipotézisek pedig a vizsgált tényezők elégedettségre való hatását hivatottak mérni.

1. ábra

\section{A kvantitatív kutatás hipotézisei}

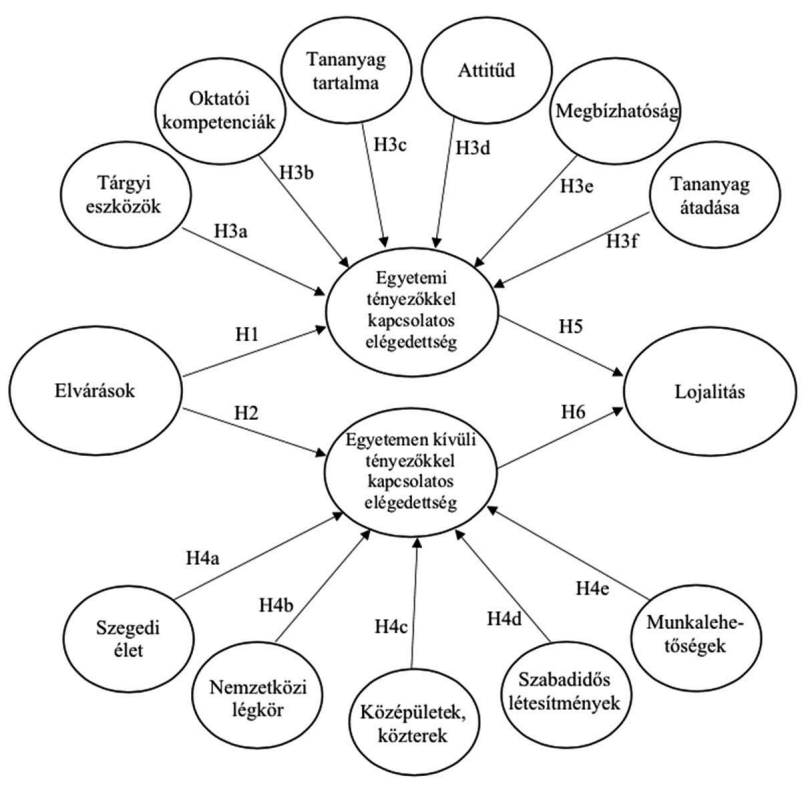

Forrás: saját kutatás, saját szerkesztés

\section{A kutatási módszertan és a minta bemutatása}

A kutatásban megjelenő fogalmak operacionalizálása szakirodalmi áttekintésen alapul, a kérdőív pedig törekszik a korábbi nemzetközi kutatásokban alkalmazott validált skálák alkalmazására (Alves \& Raposo, 2009; Mihanovic et al., 2016; Dona-Toledo et al., 2017), hiszen a Likert-skálák használata a felsőoktatásban megjelenő elvárások, elégedettség és lojalitás mérésére nemzetközileg elfogadott és alkalmazott módszertan (Turkyilmaz et al., 2018). Hat külföldi hallgató (alap-, mester- és PhD-képzésről egyaránt) segédkezett a primer kutatás kérdőívének 
tesztelésében, melynek végső formája a hallgatói visszajelzések alapján alakult ki.

Az elöző fejezetben taglalt hipotézisek teszteléséhez a felvázolt látens változók közötti kapcsolatot szükséges vizsgálni, melyre a strukturális egyenletek módszere alkalmazható, hiszen az marketing- (Kazár, 2014) és felsőoktatási kutatásokban is gyakran alkalmazott eljárás (Lee, 2010; El-Hilali et al., 2015; Giner \& Rillo, 2016). Jelen kutatásban alkalmazható a PLS-útelemzés technikája (Hair et al., 2014), hiszen az egyes változók nem tekinthetők normális eloszlásúnak (Kolmogorov-Smirnov és ShapiroWilk tesztek esetén is minden változó esetén $p<0,01)$. A PLS-útelemzés SmartPLS 3 szoftver segítségével valósult meg (Ringle et al., 2015). tett külföldi hallgatók száma a 2018/2019-es tanévben 2505 fö volt a Szegedi Tudományegyetemen. A kérdőívre összesen 192 válasz érkezett, mely az alapsokaság $7,66 \%$-a, és melyből az adattisztítás során négy választ kizártunk, hiszen az egyik a Szegedi Tudományegyetem már végzett hallgatójától érkezett, a másik három pedig Magyarországgal határos országbéli hallgatóktól, akik magyar képzésben tanulnak hazánkban. A végső minta így 188 válaszadóból állt, akiknek demográfiai adatait az 1. táblázat mutatja.

Az 1. táblázatban látható, hogy összesen 102 nő és 78 férfi tartozik a mintába, 8 fö pedig nem nyilatkozott a neméröl. A képzési szintet vizsgálva megállapítható, hogy a kitöltök legnagyobb arányban (56,9\%) osztatlan

\section{A válaszadók demográfiai jellemzői}

\begin{tabular}{|c|c|c|c|}
\hline \multicolumn{2}{|c|}{ Demográfiai tényezők } & \multirow{2}{*}{ Válaszadók száma (fö) } & \multirow{2}{*}{\begin{tabular}{|l|} 
Megoszlás (\%) \\
41,5 \\
\end{tabular}} \\
\hline \multirow{4}{*}{ Nem } & Férfi & & \\
\hline & Nő & 102 & 54,3 \\
\hline & Nem nyilatkozott & 8 & 4,2 \\
\hline & Összesen & 188 & 100 \\
\hline \multirow{5}{*}{ Képzési szint } & Alapképzés & 43 & 22,9 \\
\hline & Mesterképzés & 23 & 12,2 \\
\hline & Osztatlan képzés & 107 & 56,9 \\
\hline & PhD képzés & 15 & 8 \\
\hline & Összesen & 188 & 100 \\
\hline \multirow{5}{*}{ Képzés nyelve } & Angol & 147 & 78,2 \\
\hline & Német & 39 & 20,8 \\
\hline & Francia & 1 & 0,5 \\
\hline & Magyar & 1 & 0,5 \\
\hline & Összesen & 188 & 100 \\
\hline \multirow{3}{*}{ Tanulmányok finanszírozása } & Ösztöndíjas & 59 & 31 \\
\hline & Önköltséges & 129 & 69 \\
\hline & Összesen & 188 & 100 \\
\hline \multirow{7}{*}{ Korcsoport } & $18-20$ & 51 & 27,2 \\
\hline & $21-23$ & 72 & 38,3 \\
\hline & $24-26$ & 39 & 20,7 \\
\hline & $27-29$ & 12 & 6,4 \\
\hline & $30-$ & 13 & 6,9 \\
\hline & Nem nyilatkozott & 1 & 0,5 \\
\hline & Összesen & 188 & 100 \\
\hline
\end{tabular}

Forrás: saját kutatás, saját szerkesztés

A kérdőíves megkérdezés a Szegedi Tudományegyetemen zajlott 2019. március és április hónapban. Ezen időszak alatt az egyetem 12 karának kapcsolattartói segítségével, valamint a közösségi médián fellelhető hallgatói csoportokon keresztül osztottuk meg az elektronikus kérdőívet a vizsgálat alanyaival, vagyis a Szegedi Tudományegyetem jelenlegi külföldi, nappali, teljes (osztatlan, alap- és mesterképzésben) és részképzésben tanuló diákjaival. Az alapsokaság, vagyis az érin- képzésben vesznek részt, mely összesen 107 föt takar. Alapképzésben 43-an, mesterképzésben 23-an, PhDképzésben pedig 15-en tanulnak a kérdőívre választ adók közül. A táblázatból szintén megtudható, hogy a képzés nyelve a legtöbb esetben angol (147 fö), ám németül (39 fö), franciául (1 fó) és magyarul (1 fö) is tanulnak a kitöltő külföldi hallgatók a Szegedi Tudományegyetemen. A válaszadók többsége (69\%) önköltséges tanulmányokat folytat, míg 31\%-uk ösztöndíjjal tanul Szegeden. Az élet- 
kor tekintetében jól látható, hogy a válaszadók több mint 86\%-a 18 és 26 év közötti külföldi hallgató.

A 2. táblázat a válaszadók karok szerinti megoszlását mutatja, melyen jól látható, hogy a legnagyobb arányban az Általános Orvostudományi Karról töltötték ki a kérdőívet (56,4\%), mely összhangban van az 1. táblázat képzési szint szerinti kitöltési arányával is. A második legtöbb kitöltés a Gazdaságtudományi Karról érkezett, melynek oka az lehet, hogy őket sikerült a legkönnyebben elérni. Fontos kutatási eredmény, hogy az egyetem tizenkét kara közül összesen 11 karról érkezett válasz a hallgatóktól, egyedül a Juhász Gyula Pedagógusképző Karon nem történt kitöltés, ami azzal magyarázható, hogy az ott tanuló külföldi hallgatók száma elenyésző.

2. táblázat

\section{A válaszadók karok szerinti megoszlása}

\begin{tabular}{|l|c|c|}
\hline \multicolumn{1}{|c|}{ Kar } & $\begin{array}{c}\text { Válaszadók } \\
\text { száma (fö) }\end{array}$ & $\begin{array}{c}\text { Megoszlás } \\
\text { (\%) }\end{array}$ \\
\hline Állam- és Jogtudományi Kar & 10 & $5,3 \%$ \\
\hline Általános Orvostudományi Kar & 106 & $56,4 \%$ \\
\hline Bölcsészettudományi Kar & 9 & $4,8 \%$ \\
\hline $\begin{array}{l}\text { Egészségtudományi és Szociális } \\
\text { Képzési Kar }\end{array}$ & 3 & $1,6 \%$ \\
\hline Fogorvostudományi Kar & 10 & $5,3 \%$ \\
\hline Gazdaságtudományi Kar & 35 & $18,6 \%$ \\
\hline Gyógyszerésztudományi Kar & 2 & $1,1 \%$ \\
\hline Juhász Gyula Pedagógusképző Kar & 0 & $0,0 \%$ \\
\hline Mérnöki Kar & 2 & $1,1 \%$ \\
\hline Mezőgazdasági Kar & 2 & $1,1 \%$ \\
\hline $\begin{array}{l}\text { Természettudományi és Informati- } \\
\text { kai Kar }\end{array}$ & 4 & $2,1 \%$ \\
\hline Zeneművészeti Kar & 5 & $2,7 \%$ \\
\hline Összesen & $\mathbf{1 8 8}$ & $\mathbf{1 0 0}$ \\
\hline
\end{tabular}

Forrás: saját kutatás, saját szerkesztés
A hallgatók származási országát tekintve igen színes összetételt állapíthatunk meg, hiszen a kérdőív kitöltői 42 országból érkeztek, melyek közül a küldött hallgatók számát tekintve Németország (40 fő), Irán (19 fö), Azerbajdzsán (10 fö), Kína ( 9 fö) és Törökország ( 9 fö) a leghangsúlyosabbak, hiszen hallgatói létszámuk a minta 46\%-át adják. Hallgatói származási hely között szerepel továbbá például Belgium, Brazília, az Egyesült Arab Emirátusok, az Egyesült Királyság, az Amerikai Egyesült Államok, Egyiptom, Franciaország, Ghána, India, Izrael, Japán, Jordánia, Kanada, Kazahsztán, Mongólia, Nigéria, Norvégia, Oroszország, Pakisztán, Portugália, Spanyolország és Szíria, ám összesen 13-an nem nyilatkoztak származási országukról. Összefüggéseket fedezhetünk fel a származási ország és a választott egyetemi kar között, hiszen kiemelkedő az Orvostudományi Karon tanuló német (40 fö) és iráni (12 fö) hallgatók, valamint a Gazdaságtudományi Karon tanuló azerbajdzsáni (10 fö) hallgatók száma.

Amennyiben megvizsgáljuk a válaszadók tanulmányainak finanszírozási formáját, láthatjuk, hogy 59-en rendelkeznek ösztöndíjjal. Az ösztöndíjak típusát és azok karok szerinti bontását a 3. táblázat szemlélteti. Az intézményi sajátosság miatt sem meglepő eredmény, hogy a legtöbb önköltséges hallgató az Általános Orvostudományi Karon tanul, míg a legtöbb ösztöndíjas a Gazdaságtudományi Karon folytatja tanulmányait.

Az önköltséges válaszadók mellett négy ösztöndíjprogram jelent meg a kitöltők között, a kettős diploma (double degree), Erasmus+ program, magyar állami ösztöndíj és a Stipendium Hungaricum ösztöndíjprogram, melyek közül az Erasmus + hallgatók részképzésben tanulnak, a legnépszerübb pedig a Stipendium Hungaricum program volt. A kitöltők saját elmondása szerint 92 fő tanulmányai elején, 65 fő a közepén, 31 fö pedig a végén járt, mely tényező a kvantitatív kutatás későbbi részében (klaszterelemzés) fontos elemzési szempont lesz.

A válaszadók tanulmányainak finanszírozási formája karok szerinti bontásban

\begin{tabular}{|c|c|c|c|c|c|c|}
\hline \multirow[b]{2}{*}{ Kar } & \multirow[b]{2}{*}{ Önköltséges } & \multicolumn{5}{|c|}{ Ösztöndíjas } \\
\hline & & $\begin{array}{l}\text { Kettős diploma } \\
\text { (double degree) }\end{array}$ & Erasmus + & $\begin{array}{l}\text { Magyar állami } \\
\text { ösztöndíj }\end{array}$ & $\begin{array}{c}\text { Stipendium } \\
\text { Hungaricum }\end{array}$ & Összesen \\
\hline Állam- és Jogtudományi Kar & 2 & 0 & 2 & $\begin{array}{r}0 \\
\end{array}$ & 6 & 10 \\
\hline Általános Orvostudományi Kar & 104 & 0 & 1 & 0 & 1 & 106 \\
\hline Bölcsészettudományi Kar & 1 & 0 & 2 & 0 & 6 & 9 \\
\hline $\begin{array}{l}\text { Egészségtudományi és Szociális Képzési } \\
\text { Kar }\end{array}$ & 3 & 0 & 0 & 0 & 0 & 3 \\
\hline Fogorvostudományi Kar & 8 & 0 & 0 & 0 & 2 & 10 \\
\hline Gazdaságtudományi Kar & 4 & 1 & 1 & 1 & 28 & 35 \\
\hline Gyógyszerésztudományi Kar & 1 & 0 & 0 & 0 & 1 & 2 \\
\hline Mérnöki Kar & 0 & 0 & 1 & 0 & 1 & 2 \\
\hline Mezőgazdasági Kar & 2 & 0 & 0 & 0 & 0 & 2 \\
\hline Természettudományi és Informatikai Kar & 0 & 0 & 1 & 0 & 3 & 4 \\
\hline Zeneművészeti Kar & 4 & 0 & 0 & 0 & 1 & 5 \\
\hline Összesen & 129 & 1 & 8 & 1 & 49 & 188 \\
\hline
\end{tabular}

Forrás: saját kutatás, saját szerkesztés 
A válaszadók oktatási nyelve karok szerint

\begin{tabular}{|c|c|c|c|c|c|}
\hline \multirow{2}{*}{ Kar } & \multicolumn{4}{|c|}{ Oktatás nyelve } & \multirow{2}{*}{ Összesen } \\
\hline & Angol & Francia & Magyar & Német & \\
\hline Állam- és Jogtudományi Kar & 9 & 1 & 0 & 0 & 10 \\
\hline Általános Orvostudományi Kar & 67 & 0 & 0 & 39 & 106 \\
\hline Bölcsészettudományi Kar & 9 & 0 & 0 & 0 & 9 \\
\hline Egészségtudományi és Szociális Képzési Kar & 3 & 0 & 0 & 0 & 3 \\
\hline Fogorvostudományi Kar & 10 & 0 & 0 & 0 & 10 \\
\hline Gazdaságtudományi Kar & 35 & 0 & 0 & 0 & 35 \\
\hline Gyógyszerésztudományi Kar & 2 & 0 & 0 & 0 & 2 \\
\hline Mérnöki Kar & 1 & 0 & 1 & 0 & 2 \\
\hline Mezőgazdasági Kar & 2 & 0 & 0 & 0 & 2 \\
\hline Természettudományi és Informatikai Kar & 4 & 0 & 0 & 0 & 4 \\
\hline Zeneművészeti Kar & 5 & 0 & 0 & 0 & 5 \\
\hline Összesen & 147 & 1 & 1 & 39 & 188 \\
\hline
\end{tabular}

Forrás: saját kutatás, saját szerkesztés

Ami a válaszadók oktatási programjának nyelvét illeti, a 4. táblázatban látható, hogy az angol a legelterjedtebb oktatási nyelv, hiszen az érintett összes karon találhatunk olyan programot vagy tanórát, ahol angolul sajátítják el a tudást a hallgatók. Ezzel ellentétben a francia nyelv kimondottan az Állam- és Jogtudományi Kar sajátossága, míg a német nyelv az Általános Orvostudományi Karé. Magyar nyelven olyan, javarészt Stipendium Hungaricum ösztöndíjas hallgatók tanulhatnak, akik szegedi tanulmányaikat megelőzően magyar nyelvi előkészítőn vettek részt, a jelen mintában egy ilyen hallgató található.

\section{Kutatási eredmények}

Ebben a fejezetben a kvantitatív kutatás eredményeit mutatjuk be, kezdve a PLS-útelemzés külső, valamint belső mérési modelljeinek eredményével, melyet a faktor- és klaszterelemzés leírása követ.

\section{A külső mérési modell eredményei}

Az útelemzés külső modellje a konstrukciók megbízhatósága a Cronbach-Alfa és CR (összetétel megbízhatóság) mutatók segítségével vizsgálatos, mely mutatókról jelen kutatásra vonatkozóan elmondható, hogy mindegyik konstrukció teljesíti a minimális értéket $(>0,6$ Hair et al., 2009). A konvergenciaérvényesség ellenőrzésére a standardizált faktorsúlyokat $(>0,5)$, és az AVE (átlagos kivonatolt variancia, $>0,5)$ mutatókat szükséges megvizsgálni, melyek kapcsán a faktorsúly két item esetén nem haladta meg a minimumértéket $(>0,5)$, így ezen itemek végső modellből való kihagyása javasolt. A két item elhagyása után az összes konstrukció létezése igazolható, vagyis a végső modellben szereplő látens változók és indikátoraik a konstrukció megbízhatóság és konvergenciaérvényesség kritériumokat is teljesítik.

A diszkriminanciaérvényesség ellenőrzésére Fornell és Larcker (1981) tesztje alapján került sor, mely szerint

A diszkriminanciaérvényesség ellenőrzése a Fornell - Larcker kritérium alapján

\begin{tabular}{|c|c|c|c|c|c|c|c|c|c|c|c|c|c|c|c|}
\hline & Attitüd & $\begin{array}{l}\text { Egy.ka } \\
\text { pcs.el. }\end{array}$ & $\begin{array}{l}\text { Egy.kív } \\
\text {.elég. }\end{array}$ & Elv. & $\begin{array}{l}\text { Közép. } \\
\text { közt. }\end{array}$ & Lojalitás & Megbízh. & Munk. & $\begin{array}{l}\text { Nemz. } \\
\text { légk. }\end{array}$ & $\begin{array}{l}\text { Okt.k } \\
\text { omp. }\end{array}$ & $\begin{array}{l}\text { Szab.te } \\
\text { v. }\end{array}$ & $\begin{array}{l}\text { Szegedi } \\
\text { él. }\end{array}$ & \begin{tabular}{|l|} 
Tanany.t \\
art.
\end{tabular} & $\begin{array}{l}\text { Tanany. } \\
\text { átad. }\end{array}$ & $\begin{array}{l}\text { Tárgy. } \\
\text { eszk. }\end{array}$ \\
\hline Attitüd & 0,773 & & & & & & & & & & & & & & \\
\hline Egy.kapcs.el. & 0,544 & 0,854 & & & & & & & & & & & & & \\
\hline Egy.kív.elég. & 0,297 & 0,491 & 0,796 & & & & & & & & & & & & \\
\hline Elv. & 0,056 & 0,110 & 0,193 & 0,739 & & & & & & & & & & & \\
\hline Közép.közt. & 0,338 & 0,351 & 0,523 & 0,193 & 0,730 & & & & & & & & & & \\
\hline Lojalitás & 0,599 & 0,786 & 0,488 & 0,207 & 0,398 & 0,730 & & & & & & & & & \\
\hline Megbízh. & 0,750 & 0,533 & 0,300 & 0,087 & 0,362 & 0,587 & 0,858 & & & & & & & & \\
\hline Munk. & 0,366 & 0,340 & 0,320 & 0,028 & 0,306 & 0,285 & 0,296 & 0,875 & & & & & & & \\
\hline Nemz.légk. & 0,387 & 0,436 & 0,591 & 0,075 & 0,387 & 0,473 & 0,340 & 0,340 & 0,776 & & & & & & \\
\hline Okt.komp. & 0,564 & 0,646 & 0,379 & 0,150 & 0,365 & 0,614 & 0,639 & 0,322 & 0,364 & 0,827 & & & & & \\
\hline Szab.tev. & 0,402 & 0,477 & 0,648 & 0,120 & 0,584 & 0,509 & 0,382 & 0,319 & 0,528 & 0,387 & 0,836 & & & & \\
\hline Szegedi él. & 0,234 & 0,446 & 0,793 & 0,215 & 0,482 & 0,456 & 0,257 & 0,327 & 0,550 & 0,362 & 0,528 & 0,766 & & & \\
\hline Tanany.tart. & 0,546 & 0,700 & 0,346 & 0,125 & 0,349 & 0,681 & 0,584 & 0,271 & 0,392 & 0,689 & 0,405 & 0,310 & 0,801 & & \\
\hline Tanany.átad. & 0,641 & 0,588 & 0,369 & 0,135 & 0,390 & 0,623 & 0,637 & 0,295 & 0,319 & 0,712 & 0,398 & 0,303 & 0,712 & 0,811 & \\
\hline Tárgy.eszk. & 0,477 & 0,430 & 0,350 & 0,146 & 0,389 & 0,432 & 0,495 & 0,190 & 0,368 & 0,458 & 0,355 & 0,325 & 0,536 & 0,488 & 0,803 \\
\hline
\end{tabular}


az 5. táblázatból megállapítható, hogy minden látens változó esetén az adott látens változó AVE értékének a gyöke (az 5. táblázat fóátlójának értéke) magasabb, mint a látens változó és a többi látens változó korrelációs együtthatója.

A külső modell eredményei alapján tehát az egyes látens változók létezése igazolható, továbbá az adott látens változókhoz kapcsolódó indikátorok ugyanazt a jelenséget reprezentálják. A külső modell bemutatása után a belső mérési modell eredményeinek áttekintése következik.

\section{A belső mérési modell eredményei}

A belső modellt tekintve fontos megemlíteni, hogy a skálaváltozóknál esetlegesen hiányzó értékek az adott változók átlagaival lettek pótolva. Az útegyütthatók szignifikanciájának tesztelése bootstrap algoritmus segítségével történt (Hair et al., 2014), ahol az alkalmazott alminták száma 5000 volt.
A 6. táblázat p-értékei alapján látható, hogy hét út esetén beszélhetünk szignifikáns hatásról ötszázalékos szignifikanciaszinten. A nem szignifikáns hatásokat (melyek a H1, H2, H3a, H3d, H3e, H3f, H4c, H4e-t érintik) célszerü kihagyni a modellből, így a vonatkozó hipotéziseket elvetettük. E szerint az elvárások nincsenek hatással sem az egyetemi, sem pedig az egyetemen kívüli tényezőkkel kapcsolatos elégedettségre (H1, H2); a tárgyi eszközök, az attitüd, a megbízhatóság és a tananyag átadása (H3a, H3d, H3e, H3f) nem fejt ki szignifikáns hatást az egyetemi tényezőkkel kapcsolatos elégedettségre; a középületek, közterek és a munkalehetőségek (H4c, H4e) sem gyakorolnak hatást az egyetemen kívüli tényezőkkel kapcsolatos elégedettségre.

A hipotézisekben feltételezett nem szignifikáns utak elhagyása után a PLS-útelemzést bootstrap algoritmussal újrafuttatva, az újrafuttatott modellre vonatkozóan megállapítható, hogy az összes út esetén szignifikáns hatásról

\section{Az útegyütthatók szignifikanciájának tesztelése a hipotézisek alapján}

6. táblázat

\begin{tabular}{|l|l|l|l|l|l|}
\hline \multicolumn{1}{|c|}{ Út } & \multicolumn{1}{|c|}{$\begin{array}{c}\text { Útegyüttható } \\
\text { (eredeti minta) }\end{array}$} & $\begin{array}{c}\text { Útegyüttható } \\
\text { átlaga (a bootstrap } \\
\text { mintákból) }\end{array}$ & $\begin{array}{c}\text { Útegyüttható } \\
\text { átlagának standard } \\
\text { hibája }\end{array}$ & $\begin{array}{c}\text { t-érték } \\
\text { p-ér- } \\
\text { ték }\end{array}$ \\
\hline Attitüd -> Egy.elégedettség & 0,177 & 0,179 & 0,092 & 1,916 & 0,055 \\
\hline Egy.elégedettség -> Lojalitás & $\mathbf{0 , 7 2 0}$ & $\mathbf{0 , 7 2 3}$ & $\mathbf{0 , 0 4 9}$ & $\mathbf{1 4 , 5 6 7}$ & $\mathbf{0 , 0 0 0}$ \\
\hline Egy.kívüli.elég_-> Lojalitás & $\mathbf{0 , 1 3 5}$ & $\mathbf{0 , 1 3 5}$ & $\mathbf{0 , 0 5 9}$ & $\mathbf{2 , 2 9 9}$ & $\mathbf{0 , 0 2 2}$ \\
\hline Elvárások -> Egy.elégedettség & 0,009 & 0,015 & 0,064 & 0,141 & 0,887 \\
\hline Elvárások -> Egy.kívüli.elég & 0,022 & 0,027 & 0,052 & 0,428 & 0,669 \\
\hline Középületek, közterek -> Egy.kívüli.elég & 0,052 & 0,055 & 0,061 & 0,856 & 0,392 \\
\hline Megbízhatóság -> Egy.elégedettség & $-0,016$ & $-0,017$ & 0,088 & 0,186 & 0,853 \\
\hline Munkalehetöségek -> Egy.kívüli.elég & $-0,005$ & $-0,005$ & 0,042 & 0,122 & 0,903 \\
\hline Nemzetközi légkör -> Egy.kívüli.elég & $\mathbf{0 , 1 2 9}$ & $\mathbf{0 , 1 3 1}$ & $\mathbf{0 , 0 5 9}$ & $\mathbf{2 , 1 7 6}$ & $\mathbf{0 , 0 3 0}$ \\
\hline Oktatói kompetenciák -> Egy.elégedettség & $\mathbf{0 , 2 6 3}$ & $\mathbf{0 , 2 5 9}$ & 0,072 & 3,200 & 0,001 \\
\hline Szabadidős létesítmények -> Egy.kívüli.elég & 0,252 & 0,249 & 0,055 & 3,522 & 0,000 \\
\hline Szegedi élet -> Egy.kívüli.elég & 0,561 & 0,559 & 0,088 & 10,281 & 0,000 \\
\hline Tananyag tartalma -> Egy.elégedettség & 0,443 & 0,438 & 0,088 & 5,054 & 0,000 \\
\hline Tananyag átadása-> Egy.elégedettség & $-0,020$ & $-0,018$ & 0,066 & 0,228 & 0,820 \\
\hline Tárgyi eszközök -> Egy.elégedettség & 0,004 & 0,009 & 0,058 & 0,954 \\
\hline
\end{tabular}

Forrás: saját kutatás, saját szerkesztés

\section{A végső modellben megjelenő útegyütthatók szignifikanciájának tesztelése}

\begin{tabular}{|l|l|l|l|l|l|}
\hline \multicolumn{1}{|c|}{ Út } & \multicolumn{1}{|c|}{$\begin{array}{c}\text { Útegyüttható } \\
\text { (eredeti minta) }\end{array}$} & $\begin{array}{c}\text { Útegyüttható } \\
\text { átlaga (a bootstrap } \\
\text { mintákból) }\end{array}$ & $\begin{array}{c}\text { Útegyüttható } \\
\text { átlagának standard } \\
\text { hibája }\end{array}$ & t-érték & p-érték \\
\hline Egy.elégedettség -> Lojalitás & 0,720 & 0,723 & 0,049 & 14,668 & 0,000 \\
\hline Egy.kívüli.elég -> Lojalitás & 0,135 & 0,134 & 0,059 & 2,287 & 0,022 \\
\hline Nemzetközi légkör -> Egy.kívüli.elég & 0,127 & 0,129 & 0,058 & 2,195 & 0,028 \\
\hline Oktatói kompetenciák -> Egy.elégedettség & 0,312 & 0,311 & 0,076 & 4,094 & 0,000 \\
\hline Szabadidös létesítmények -> Egy.kívüli.elég & 0,275 & 0,274 & 0,061 & 4,515 & 0,000 \\
\hline Szegedi élet -> Egy.kívüli.elég & 0,578 & 0,579 & 0,056 & 10,343 & 0,000 \\
\hline Tananyag tartalma -> Egy.elégedettség & 0,485 & 0,487 & 0,066 & 7,299 & 0,000 \\
\hline
\end{tabular}

Forrás: saját kutatás, saját szerkesztés 
beszélhetünk ötszázalékos szignifikanciaszinten (7. táblázat). Fontos leszögezni, hogy a külső modell esetében megjelenő mutatók és kritériumok (Cronbach-alfa, CR, AVE, standardizált faktorsúlyok, Fornell-Larcker kritérium) megítélése a nem szignifikáns utak kihagyásával nem változott.

A 2. ábrán látható a szignifikáns hatások figyelembevételével kialakított végső modell, melyről megállapítható, hogy a közvetlen hatások esetén a standardizált útegyütthatók alapján az egyes látens változók között minden párosítás esetén pozitív hatásokkal számolhatunk. A standardizált útegyütthatókról $(\beta)$ pedig az alábbiak mondhatók el:

- az egyetemi tényezőkkel való elégedettségre a tananyag tartalma $(\beta=0,485)$ erősebb hatást fejt ki, mint az oktatói kompetenciák $(\beta=0,312)$,

- az egyetemen kívüli tényezökkel kapcsolatos elégedettségre a szegedi élet $(\beta=0,578)$ fejt ki legerösebb hatást, melyet a szabadidős létesítmények $(\beta=0,275)$, majd pedig a nemzetközi légkör $(\beta=0,127)$ követ,

- a külföldi hallgatók lojalitására legerősebben az egyetemi tényezőkkel kapcsolatos elégedettség $(\beta=0,720)$ hat, az egyetemen kívüli tényezők ennél jóval gyengébb hatást mutatnak $(\beta=0,135)$.

2. ábra

A Szegedi Tudományegyetem külföldi hallgatóinak elégedettségére és lojalitásra ható tényezői

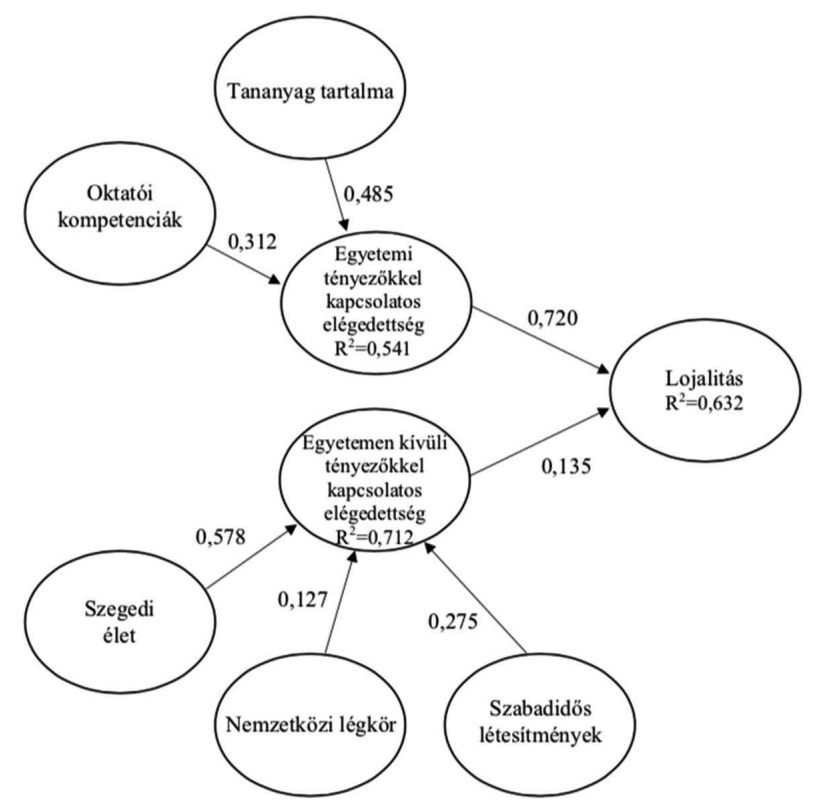

Forrás: saját kutatás, saját szerkesztés

Ezen eredmények alapján elmondható, hogy a H3b, H3c, H4a, H4b, H4d, H5 és H6 hipotéziseket elfogadjuk. Az egyetemi tényezőkkel kapcsolatos elégedettségre hat az oktatói kompetenciák és a tananyag tartalma (H3b, H3c), az egyetemi tényezőkkel kapcsolatos elégedettségre pedig a szegedi élet, a nemzetközi légkör és a szabadidős létesítmények (H4a, H4b, H4d). Mindkét elégedettségtípus hatást fejt ki a lojalitásra (H5, H6). A tanulmány fókuszában az elégedettség különböző tényezőinek vizsgálata és azok lojalitásra való hatása áll, így célszerü ezek mentén a modellben szereplő indirekt hatások, így pedig a teljes hatások vizsgálata is. Az oktatói kompetenciák lojalitásra kifejtett közvetett hatása $(\beta=0,225)$ az egyetemi tényezőkkel kapcsolatos elégedettségen keresztül jelenik meg $(=0,312 * 0,720)$, hasonlóan a tananyag tartalmának lojalitásra kifejtett $(\beta=0,349)$ közvetett hatásához $\left(=0,485^{*} 0,720\right)$. A szabadidős létesítmények az egyetemen kívüli tényezőkkel kapcsolatos elégedettségen keresztül $\left(=0,275^{*} 0,135\right)$ hatnak közvetetten a lojalitásra $(\beta=0,037)$, melyhez hasonlóan gyenge közvetett hatást fejt ki a szegedi élet a lojalitásra $(\beta=0,078)$ az egyetemen kívüli tényezőkkel való elégedettségen keresztül $\left(=0,578^{*} 0,135\right)$. A többszörös determinációs együtthatók (vagyis az ellipszisekben megjelenő értékek) alapján a modellben megjelenő magyarázóerők közepesen erősnek tekinthetők. Fontos kiemelni, hogy habár az útegyüttható magasabb értéket mutat az egyetemi tényezőkkel kapcsolatos elégedettség és a lojalitás között, ennél az elégedettség látens változónál alacsonyabb a determinációs együttható értéke $\left(\mathrm{R}^{2}=0,541\right)$, míg az egyetemen kívüli tényezőkkel kapcsolatos elégedettség esetén magasabb $\left(\mathrm{R}^{2}=0,712\right)$.

Érdemes még szót ejteni a modellben lévő változók közötti hatások jelentőségéről is az $\mathrm{f}^{2}$ mutató alapján, mely az endogén változó determinációs együtthatójában bekövetkező változást vizsgál egy exogén változó elhagyása esetén (Hair et al., 2014).

8. táblázat

A változók közötti hatások jelentősége

\begin{tabular}{|l|c|}
\hline \multicolumn{1}{|c|}{ Út } & $\mathbf{f}^{\mathbf{2}}$ \\
\hline egy.elég. --> lojalitás & 1,07 \\
\hline egy.kív.elég. --> lojalitás & 0,037 \\
\hline nemz.légk. --> egy.kív.elég. & 0,035 \\
\hline okt.komp --> egy.elég. & 0,061 \\
\hline szabid.lét. --> egy.kív.elég. & 0,117 \\
\hline szeg.élet --> egy.kív.elég. & 0,623 \\
\hline tan.tart. --> egy.elég. & 0,175 \\
\hline
\end{tabular}

Forrás: saját kutatás, saját szerkesztés

A 8. táblázat alapján elmondható, hogy gyenge, közepes és erös hatásokról beszélhetünk a modellben. Kiemelhető és erősnek tekinthető az egyetemmel kapcsolatos elégedettség lojalitásra való hatása, valamint a szegedi élet egyetemen kívüli elégedettségre kifejtett hatása. Közepes hatásról beszélhetünk a szabadidős létesítmények és az egyetemen kívüli elégedettség, valamint az oktatói kompetenciák és az egyetemmel kapcsolatos elégedettség esetén. Ugyanakkor a további, kevésbé jelentős hatásokat sem szabad figyelmen kívül hagyni, mert a modellben megjelenő utak mindegyike szignifikánsnak tekinthető ötszázalékos szignifikanciaszinten. 


\section{A lojalitás vizsgálata faktor- és klaszterelemzéssel}

A tanulmány céljai közé tartozik a külföldi hallgatók lojalitásának mélyebb megismerése, ezért a PLSútelemzésen felül, vagyis a lojalitásra ható tényezők feltárásán kívül a kitöltők lojalitását további faktor- és klaszterelemzéssel vizsgálja. Miután a reliabilitás analízis szerint lehetséges volt az új változók képzése, a lojalitásra vonatkozó skálákat fókomponens-elemzéssel (Principal Component Analysis) vizsgálva, a KMO mutató és a Bartlett teszt szerint van értelme a háttérstruktúra keresésének. A két mesterséges változó közötti információtartalom kiegyenlítésére Varimax rotáció segítségével került sor, mely eredményeképp a 9. táblázatban látható kétfaktoros megoldás javasolható. dendrogram javaslatainak megfontolását követően a szórt pontdiagram alapján (3. ábra) sikerült végső döntést hozni a klaszterek számát illetően, hiszen a három klaszteres megoldás esetén a csoportok megfelelően elkülönülnek egymástól. A klaszterek a 10. táblázatban láthatók.

Az eredmények alapján elmondható, hogy a kitöltők három klaszterbe sorolhatók. Az átlagok értelmezésének segítségével azt a következtetést vonhatjuk le, hogy az első klaszter esetén a hallgatók inkább az egyetemhez, míg a második klaszternél inkább az élményhez lojálisak, így „egyetem és élménylojális hallgatóknak” nevezhetjük őket. A harmadik klaszter azon hallgatókat fogja össze, akik sem az egyetemhez sem pedig az élményhez nem lojálisak, így ők „,nem lojális hallgatóknak” nevezhetők el. Arányukat tekintve a nem lojális hallgatók egyértelműen

A lojalitásra vonatkozó faktorelemzés eredménye

9. táblázat

\begin{tabular}{|l|l|l|}
\hline \multicolumn{1}{|c|}{ Állítások } & Egyetemhez kapcsolódó lojalitás & Élményhez kapcsolódó lojalitás \\
\hline Szeretnék valamit visszaadni az egyetem számára, miután végeztem. & 0,656 & \\
\hline Jó kapcsolatot ápolok a kollégáimmal és oktatóimmal. & 0,602 & \\
\hline Közelinek érzem magamhoz az egyetem imázsát. & 0,686 & \\
\hline Tiszteletben tartom az egyetem irányelveit és tradícióit. & 0,558 & \\
\hline Hajlandó vagyok másokra is hatni, hogy tanuljanak itt. & 0,637 & \\
\hline Megvédeném az egyetememet más egyetemekkel szemben. & 0,714 & \\
\hline $\begin{array}{l}\text { A következő diplomámat is itt a Szegedi Tudományegyetemen } \\
\text { csinálnám. }\end{array}$ & 0,765 & 0,808 \\
\hline Jó emlékeim vannak az egyetemen való tanulásról. & & 0,772 \\
\hline Jó emlékeim vannak/lesznek az itt töltött időröl. & & 0,776 \\
\hline Másoknak is ajánlanám a külföldön való tanulást. & & 0,676 \\
\hline Újra nekivágnék a külföldi tanulásnak. & & \\
\hline Felnézek a mentoromra vagy az egyetemi oktatókra. * & & \\
\hline
\end{tabular}

*Az állitáshoz azért nem tartozik számérték, mert a 0,5 feletti értékek kerültek megjelenítésre a faktorelemzés során.

Forrás: saját kutatás, saját szerkesztés

Az elemzés alapján megállapítható, hogy két faktort különíthetünk el egymástól, melyeknek a hozzájuk tartozó ismérvek alapján az alábbi két elnevezés adható:

1. faktor: Egyetemhez kapcsolódó lojalitás

2. faktor: Élményhez kapcsolódó lojalitás

Az egyetemhez kapcsolódó lojalitás faktoron belül olyan kérdéseket találunk, melyek arra vonatkoznak, hogy a külföldi hallgatók szeretnek az egyetemen tanulni, jó kapcsolatot ápolnak az ott dolgozókkal, hajlandóbbak ajánlani másoknak és újraválasztani az intézményt, ezzel szemben az élményhez kapcsolódó faktor esetén a kérdések inkább arra vonatkoznak, hogy a külföldi hallgatók emlékei és élményei a meghatározók az egyetemen töltött időről és tanulásról, továbbajánláskor pedig a külföldi tanulási élményt hangsúlyozzák.

A faktorelemzést követően hierarchikus klaszterelemzés segített a kitöltőket különböző jól elkülöníthető csoportokba osztani a már meglévő faktorok alapján, Ward metódussal és euklédeszi távolság alkalmazásával. A kisebbségben vannak, hiszen a válaszadók csupán 11,7\%a tekinthető nem lojálisnak, míg 41,5\%-uk egyetem-, 46,8\%-uk élménylojális.

\section{3. ábra}

\section{A klaszterelemzés szórt pontdiagramja}

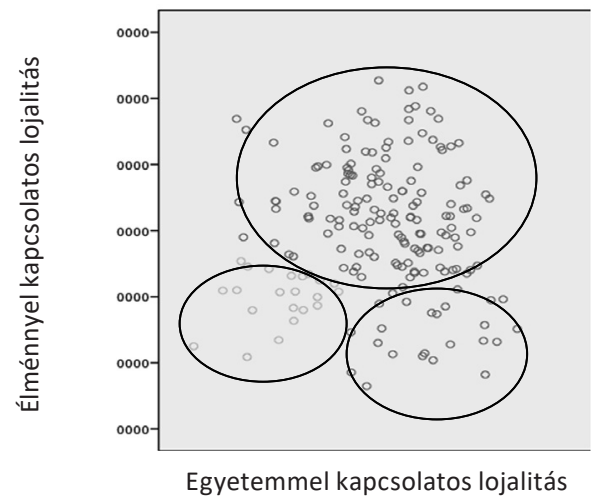

Forrás: saját kutatás, saját szerkesztés 
10. táblázat

A klaszterelemzés eredménye

\begin{tabular}{|c|l|l|l|}
\hline \multicolumn{2}{|c|}{ Ward módszer } & \multicolumn{1}{|c|}{$\begin{array}{c}\text { Élményhez } \\
\text { kapcsolódó } \\
\text { lojalitás }\end{array}$} & $\begin{array}{c}\text { Egyetemhez } \\
\text { kapcsolódó } \\
\text { lojalitás }\end{array}$ \\
\hline \multirow{3}{*}{1} & Átlag &,- 6145721 &, 7406690 \\
\cline { 2 - 4 } & Elemszám & 78 & 78 \\
\cline { 2 - 4 } & Szórás &, 73415670 &, 62016140 \\
\hline \multirow{3}{*}{2} & Átlag &, 7965517 &,- 2865019 \\
\cline { 2 - 4 } & Elemszám & 88 & 88 \\
\cline { 2 - 4 } & Szórás &, 63130670 &, 77468520 \\
\hline \multirow{3}{*}{3} & Átlag & $-1,0072695$ & $-1,4800007$ \\
\cline { 2 - 4 } & Elemszám & 22 & 22 \\
\cline { 2 - 4 } & Szórás &, 39080671 &, 57617831 \\
\hline \multirow{3}{*}{ Összesen } & Átlag &, 0000000 &, 0000000 \\
\cline { 2 - 4 } & Elemszám & 188 & 188 \\
\cline { 2 - 4 } & Szórás & 1,00000000 & 1,00000000 \\
\hline
\end{tabular}

Forrás: saját kutatás, saját szerkesztés

A klaszterek jellemzőit kereszttábla segítségével megvizsgálva azt láthatjuk, hogy az egyetemlojális hallgatók többnyire osztatlan képzésben részt vevő költségtérítéses női hallgatók, míg az élménylojális hallgatók többsége alap-, osztatlan és PhD-képzésről származó férfi, akik többnyire ösztöndíjjal rendelkeznek. Nem lojális hallgatókat minden képzési szinten találunk, kivéve a PhD-képzést.

Érdekes eredményeket hozott a klaszterek karok szerinti elemzése is, ami azt mutatja, hogy az egészségügyi (szociális munkás, ápoló, orvos és fogorvosképzés) és jogi, tehát az osztatlan képzésben résztvevök az egyetemlojálisak, míg a zenemüvészeti, bölcsészettudományi, gazdaságtudományi és informatikai karon inkább az élménylojalitás jellemző. A nem lojális hallgatói klaszterbe hat karról érkezö hallgatók tartoznak.

Fontos azt is leszögezni, hogy az eredmények alapján a lojalitás a felsőoktatási intézményben eltöltött idővel kialakulhat, hiszen az eredmények azt mutatják, hogy első évben a hallgatók nagyobb arányban vallják magukat nem lojálisnak, mely arányszám az évek előrehaladtával csökkenő tendenciát mutat.

\section{Összefoglalás}

A tanulmány központi célja az volt, hogy a Szegedi Tudományegyetem példáján keresztül megvizsgálja, hogy milyen egyetemi és nem egyetemi tényezők befolyásolják a külföldi hallgatók elégedettségét, és az elégedettség miként hat a lojalitásra. A kutatás további céljai között szerepelt a külföldi hallgatók lojalitásának mélyebb megértése is.

\section{Elméleti következtetések}

A kvantitatív kutatás eredményei között talán nem meglepő az, hogy az oktatói kompetenciák és a tananyag tartalma jelentős hatást fejtenek ki az egyetemmel kapcsolatos elégedettségre, valamint közvetetten hatnak a lojalitásra is. Az egyetemmel kapcsolatos elégedettség erős hatást fejt ki a lojalitásra, ám érdekes eredménynek tekinthető, hogy az egyetemen kívüli elégedettség is hatással van a lojalitásra. Az egyetemen kívüli elégedettségre a szegedi élet, a nemzetközi légkör és a szabadidős létesítmények hatnak, melyek közül a szegedi élet és a szabadidős létesítmények közvetetetten is hatnak a lojalitásra. A faktor- és klaszterelemzés eredményeképp lojalitásuk tekintetében a válaszadók három csoportra bonthatók, akiket az adott klaszterben szereplő állítások alapján élmény, egyetemlojális, valamint nem lojális külföldi hallgatóknak nevezhetünk.

Ami az elvárásokat illeti, az eredmények alapján, habár igazolható az elvárások látens változó létezése, nem tekinthetünk rájuk befolyásoló tényezőként, mert nincsenek szignifikáns hatással az elégedettségre, így inkább értékítéletet és véleményt meghatározó tényezőként értelmezhetjük (Billups, 2008). Ennek oka többek között az lehet, hogy nem minden hallgató rendelkezik tisztán megfogalmazott elvárással a külföldön tanulással kapcsolatosan, valamint az elvárások (a hallgatók saját elmondása szerint) a képzés folyamán is alakulhatnak és módosulhatnak. Ez az eredmény azért is fontos, mert az elvárások és elégedettség témakörét gyakran együtt vizsgálják a felsőoktatási környezetben is (Alves \& Raposo, 2009), azonban az eredmények alapján a két fogalom közötti kapcsolat nem minden esetben igazolható primer kutatás segítségével. Az elvárások témaköre mindazonáltal fontos része a külföldi hallgatókkal kapcsolatos kutatásoknak, hiszen annak vizsgálata, hogy mit várnak el az általuk választott felsőoktatási intézménytől és külföldi országtól meghatározó lehet továbbtanulásuk folyamán, az intézmény számára pedig kulcsfontosságú információként szolgálhat (Eurico et al., 2015), így további kutatása ajánlott.

Ami az elégedettséget illeti, az eredmények alapján nem az elvárások és a tapasztalatok szubjektív összehasonlításaként, hanem inkább a szolgáltatás igénybevétele (használat) és vásárlás eredményeként tekinthetünk rá (Churchill \& Surprenant, 1982), hiszen az elvárásoknak nem volt szignifikáns hatása a kutatásban vizsgált elégedettség dimenziókra. A mérési modell az egyetemmel, valamint az egyetemen kívüli tényezőkkel kapcsolatos külföldi hallgatói elégedettséget vizsgálta. Érdekes és tanúságos felfedezésként említhetjük, hogy sem a tárgyi eszközök, sem pedig az oktatók és adminisztratív dolgozók attitüdje sincsen hatással a hallgatók egyetemmel kapcsolatos elégedettségére, annak ellenére, hogy e tényezők elégedettségre gyakorolt hatását korábban számos kutatás kimutatta (Chui et al., 2016; Papanthymou \& Darra, 2017). Ezzel szemben viszont nagyon fontos volt a kitöltők számára az oktatók kompetenciája és a tananyag tartalma, mely más kutatásokban is megjelennek, mint elégedettséget befolyásoló tényezők (Yousapronpaiboon, 2014; Chui et al., 2016). Ezekből az eredményekből arra következtethetünk, hogy amennyiben az oktató megfelelö tudással rendelkezik és a tananyag, melyet tanít megfelelö, a hallgatók elégedettek lesznek, hiszen nem számít, hogy milyen környezetben tanulnak és milyen attitüddel állnak hozzájuk, ha a tanítás jó minőségű.

Az egyetemen kívüli tényezőkkel kapcsolatos elégedettség kapcsán is fontos eredmények születtek, hiszen 
a külföldi hallgatók számára legfontosabb tényezők a szegedi élet, a jó nemzetközi légkör és a szabadidő eltöltésére alkalmas létesítmények, mely eredmény összhangban van a korábbi kutatásokkal (Evans, 1972; Hetesi \& Kürtösi, 2008; Billups, 2008). Kevésbé járulnak hozzá elégedettségükhöz a középületek, a közterek és a munkavállalási lehetőségek, melyek, habár korábbi kutatásokban felmerültek, jelen kvantitatív kutatásban nem mutatkozott meg befolyásoló szerepük (Schertzer \& Schertzer, 2004).

A lojalitás fogalmának kezdeti meghatározása kellőképpen alátámasztottnak bizonyult, így a lojalitás esetleges újraválasztás mellett pozitív attitüdként, elkötelezettségként és továbbajánlásként értelmezhető. Fontos és érdekes felfedezés, hogy mind az egyetemmel kapcsolatos, mind pedig az egyetemen kívüli tényezőkkel való elégedettség szignifikáns pozitív hatást fejt ki a külföldi hallgatók lojalitására, tehát a lojalitást nem csupán az egyetemmel kapcsolatos tényezők befolyásolják, hanem abban meghatározó tényezőként szerepel a külföldi tanulási élmény, vagyis a szegedi élet és a szabadidős létesítmények megléte. A kutatás alapján tehát a mintában szereplő külföldi hallgatók lojalitásához több tényező is vezethet. Lojálisak lehetnek, ha elégedettek az oktatói kompetenciákkal, a tananyaggal, a szegedi élettel és a szabadidős létesítményekkel, melyből azt a következtetést vonhatjuk le, hogy amennyiben elégedett és lojális hallgatókat szeretne a Szegedi Tudományegyetem, az oktatáson kívül figyelmet kell szentelnie az egyetemen kívüli hallgatói életnek is, melyre, habár nagy befolyása nincsen, különböző szabadidős programok és tevékenységek szervezésével erősítheti a közösséget.

A lojalitás vizsgálatakor továbbá bebizonyosodott, hogy a szakirodalom alapján pozitív szájreklámmal, vagyis továbbajánlással való mérése is megalapozott (Mekic \& Mekic, 2016). A korábbi kvalitatív kutatásban feltárt lojalitás dimenzióinak (Kéri, 2019) kérdőíves vizsgálata alapján a lojalitás Szegedi Tudományegyetemre vonatkozó sajátossága, hogy három részre bontható a szerint, hogy a hallgatók lojálisak-e és ha igen, akkor kihez és mihez lojálisak: az élménylojális hallgatók a külföldön való tanuláshoz és élményszerzéshez, míg az egyetemlojális diákok magához az egyetemhez és oktatóikhoz lojálisak, valamint olyan hallgatók is vannak, akik nem tekinthetők lojálisnak. Ez a csoportosíthatóság azt mutatja, hogy a külföldi hallgatók lojalitását érdemes és szükséges is mélységeiben vizsgálni, hiszen a fogalom többrétű. Léteznek olyan hallgatók, akik az egyetemhez, annak tradícióihoz, oktatóikhoz és mentoraikhoz lojálisak, ám olyanok is akadnak, akik nem kimondottan az egyetemhez, hanem a külföldi tanulási élményhez lojálisak, mely tényezőket stratégiai szinten kell figyelembe venni.

Jelen kutatás eredményei hasznosak lehetnek a tudományos szféra számára, hiszen a dolgozat a külföldi hallgatók elégedettségét nem csupán a szolgáltatásminőség koncepció szempontjából vizsgálja. A lojalitás definiálása, valamint az egyetemlojális és élménylojális hallgatók elkülönítése is újító eredménynek számít, mely kimondottan a Szegedi Tudományegyetem számára lehet továbbá hasznos. A kutatás során felállított elméleti modell alapját képezheti más intézményekben, vagy akár intézményi karokon belül lebonyolított elégedettség és lojalitásvizsgálatoknak is.

\section{Menedzseri következtetések}

A kutatás eredményei a felsőoktatási intézmény döntéshozói szemszögéből is fontosak, hiszen a gyakorlatra vonatkozóan is számos javaslat fogalmazható meg. A külföldi hallgatók elégedettségét közepesen erősen befolyásolják az oktatói kompetenciák és a tananyag tartalma, az egyetemi tényezőkkel való elégedettség pedig erős hatást fejt ki a lojalitásra, így mindenképpen fontos ezeknek az elemeknek a hangsúlyozása az egyetemi marketingtevékenységek kidolgozásakor. Továbbá azt sem szabad elfelejteni, hogy a szegedi élet, a nemzetközi légkör és a szabadidős létesítmények mind hatással vannak az egyetemen kívüli tényezőkkel való elégedettségre, melyek szignifikáns hatást fejtenek ki a lojalitásra. Az egyetem marketingtevékenységeiböl így nem maradhat ki ennek a három tényezőnek a hangsúlyozása még annak ellenére sem, hogy az intézménynek ezekre a tényezőkre nincsen befolyása. A külföldi hallgatói lojalitás elérése intézményi célként kell, hogy megjelenjen, melynek erősítéséhez az egyetem is hozzájárulhat. Az élménylojális hallgatók számára javaslatként felmerülhet az egyetemen kívül, ám egyetem által rendezett szabadidős programok, közösségépítő tevékenységek szervezése, oktatók közösségi életbe való bevonása, míg az egyetemlojális hallgatók számára további egyetemhez köthető szakkörök, versenyek, megmérettetések rendszeres megrendezése, mely tevékenységek kialakíthatják, vagy tovább erősíthetik lojalitásukat. A külföldi hallgatói lojalitás erősítése kulcsfontosságú, hiszen a lojalitás esetén megjelenő pozitív szájreklám az egyetemi marketingtevékenységeket kiegészítő hatékony toborzó eszköz.

\section{A kutatás korlátai és jövőbeli kutatási irányok}

A jelen kutatásnak számos korlátja is említhető, hiszen a kvantitatív kutatásban alkalmazott kérdőív hossza nem könnyítette meg a kérdöív kitöltést, valamint az eredmények csupán egy magyarországi egyetem külföldi hallgatóira vonatkoznak, így felmerül kérdésként, hogy vajon az alkalmazott módszertani eszközök hasonló kimenetelt eredményeznének-e más magyarországi vagy külföldi egyetemen. Fontos azt is kiemelni, hogy a kutatás nem tekinthető reprezentatívnak, hiszen egyfelöl a kérdőív kitöltők száma nem érte el a 10\%-ot, másfelől volt olyan egyetemi kar, ahonnan nem érkezett kitöltés, habár tanulnak ott külföldi hallgatók.

Az eredmények alapján izgalmas kutatási irány lehet a magyarországi egyetemek külföldi hallgatóinak öszszehasonlító vizsgálata, vagy magyarországi és külföldi egyetemek összehasonlítása, mely lehetőséget biztosítana a felállított modell más egyetemeken, vagy akár kari szinten történő lekérdezésére, mely alapján esetleges diszciplináris, kari vagy egyetemek közötti különbségekre lehetne rávilágítani. Érdekes lenne továbbá finanszírozási forma és ösztöndíjtípus szerint vizsgálni a hallgatói elégedettséget és lojalitást. 


\section{Felhasznált irodalom}

Aldemir, C. \& Gülcan, Y. (2004). Student Satisfaction in Higher Education: A Turkish Case. Higher Education Management and Policy, OECD Publishing, 16(2), 109-122.

https://oi.org/10.1787/hemp-v16-art19-en

Alves, H. \& Raposo, M. (2009). The measurement of the construct satisfaction in higher education. Service Industries Journal, 29(2), 203-218. https://doi.org/10.1080/02642060802294995

Berács, J., Bander K., Hubert J. \& Nagy G. (2014). A felsőoktatási mobilitást akadályozó és ösztönző tényezők Magyarországon: 1. kötet. Budapest: Tempus Közalapítvány.

Billups, F. D. (2008). Measuring College Student Satisfaction: A Multi-Year Study of the actors Leading to Persistence. Paper presented at the 39th annual meeting of the Northeastern Educational Research Association, October 23, 2008, Rocky Hill, CT. https://core.ac.uk/download/pdf/302380957.pdf

Bryla, P. (2015). The impact of international student mobility on subsequent employment and professional career. a large-scale survey among polish former Erasmus students. Procedia, Social and Behavioral Sciences, 176, 633-641. https://doi.org/10.1016/j.sbspro.2015.01.521

Byrne, M. \& Flood, B. (2005). A study of accounting students' motives, expectations and preparedness for higher education. Journal of Further and Higher Education, 29(2), 111-124. https://doi.org/10.1080/03098770500103176

Byrne, M., Flood, B., Hassall, T., Montano, J. L. A., González, J. M. G. \& Tourana-Germanou, E. (2012). Motivations, expectations and preparedness for higher education: A study of accounting students in Ireland, the UK, Spain and Greece. Accounting Forum, 36(2), 134-144.

https://doi.org/10.1016/j.accfor.2011.12.001

Cardozo, R. (1965). An Experimental Study of Customer Effort, Expectation, and Satisfaction. Journal of Marketing Research, 2(3), 244-249.

https://doi.org/10.2307/3150182

Cardona, M. M. \& Bravo, J. J. (2012). Service quality perceptions in higher education institutions: the case of a Colombian university. Estudios Gerenciales, 28(125), 23-29. https://doi.org/10.1016/S0123-5923(12)70004-9

Chui, T. B., Ahmad, M. S., Bassim, F. A. \& Zaimi, A. (2016). Evaluation of Service Quality of Private Higher Education using Service Improvement Matrix. Procedia - Social and Behavioral Sciences, 224, 132-140. https://doi.org/10.1016/j.sbspro.2016.05.417

Churchill, G. A. \& Surprenant, C. (1982). An investigation into the determinants of customer satisfaction. Journal of Marketing Research, 19(4), 491-504. https://doi.org/10.2307/3151722

Császár, Zs. M. \& Wusching, Á. T. (2014). A Pécsi Tudományegyetem a külföldi hallgatók vonzásában.
Területfejlesztés és Innováció, 8(1), 10-21. https://epa. oszk.hu/01900/01951/00019/pdf/teruletfejlesztes_es_ innovacio_2014 1_10-21.pdf

Császár, Zs. M. \& Alpek, L. B. (2018). A nemzetközi hallgatók vidéki egyetemvárosokra gyakorolt gazdasági szerepe Magyarországon Pécs példáján. Közép-Európai Közlemények, XI, 2(41), 30-41. https:// ojs.bibl.u-szeged.hu/index.php/vikekkek/article/ view/12484

Doña-Toledo, L., Luque-Martínez, T. \& Barrio-Garía, S. (2017). Antecedents and consequences of university perceived value, according to graduates: The moderating role of Higher Education involvement. International Review on Public and Nonprofit Marketing, 14(4), 535-565. https://oi.org/10.1007/s12208-017-0186-y

El-Hilali, N., Al-Jaber, S. \& Hussein, L. (2015). Students' satisfaction and achievement and absorption capacity in higher education. Procedia - Social and Behavioral Sciences, 177, 420-427.

https://doi.org/10.1016/j.sbspro.2015.02.384

Elkhani, N. \& Bakri, A. (2012). Review on Expectancy Disconfirmation Theory (EDT) model in B2C e-commerce. Journal of Research and Innovation in Information Systems, 2, 1-13. http://eprints. utm.my/id/eprint/33036/2/AryatiBakri2012_ ReviewonExpectancyDisconfirmationTheory.pdf

Elliot, K. M. \& Healy, M. A. (2001). Key factors influencing student satisfaction related to recruitment and retention. Journal of Marketing for Higher Education, 10(4), 1-11. https://doi.org/10.1300/J050v10n04_01

Eurico, S. T., Silva, J. A. M. \& Valle, P. O. (2015). A model of graduates' satisfaction and loyalty in tourism higher education: The role of employability. Journal of Hospitality, Leisure, Sport and Tourism, 16, 30-42. http://dx.doi.org/10.1016/j.jhlste.2014.07.002

Evans, C. M. (1972). A Study of Personality Need Factors with Respect to College Student Satisfaction in a Small Church Related College Located in a Southern State. Counseling and Personnel Services (CG008971).

Fornell, C. \& Larcker, D. F. (1981). Evaluation Structural Equation Models with Unobservable Variables and Measurement Error. Journal of Marketing Research, 18(1), 39-50. https://doi.org/10.2307/3151312

Giner, G. R. \& Rillo, A. P. (2016). Structural equation modelling of co-creation and its influence on the student's satisfaction and loyalty towards university. Journal of Computational and Applied Mathematics, 291, 257-263. https://doi.org/10.1016/j.cam.2015.02.044

Gregg, W. E. (1972). Several factors affecting graduate student satisfaction. Journal of Higher Education, 43(6), 483-498. https://doi.org/10.1080/00221546.1972.11774977

Hair, J. F., Black, W. C., Babin, B. J. \& Anderson, R. E. (2009). Multivariate Data Analysis. Upper Saddle River: Prentice Hall. 
Hair, J. F., Hult, G. T. M., Ringle, C. M. \& Sarstedt, M. (2014). A primer on partial least squares structural equation modelling (PLS-SEM). London: Sage Publication.

Hetesi E. \& Kürtösi Zs. (2008). Ki ítéli meg a felsőoktatási szolgáltatások teljesítményét és hogyan? A hallgatói elégedettség mérési modelljei, empirikus kutatási eredmények az aktív és a végzett hallgatók körében. Vezetéstudomány, 39(6) 2-17.

https://doi.org/10.14267/VEZTUD.2008.06.01

Hetesi E. \& Kürtösi Zs. (2011). The Diversity of Research at the Szeged Institute of Business Studies. Szeged: Jatepress.

Hrubos I. (2017). A felsőoktatás nemzetközi környezete. Educatio, 26(4), 591-602. https://doi.org/10.1556/2063.26.2017.4.7

Huybers, T., Louviere, J. \& Islam, T. (2015). What determines student satisfaction with university subjects? A choice-based approach. Journal of Choice Modelling, 17, 52-65.

https://doi.org/10.1016/j.jocm.2015.10.001

Jager, J. \& Gbadamosi, G. (2013). Predicting students' satisfaction through service quality in higher education. International Journal of Management Education, 11(3), 107-118.

https://doi.org/10.1016/j.ijme.2013.09.001

Kasza, G. \& Hangyál, Zs. (2018). Stipendium Hungaricum scholarship holders' expectations and attitudes. Budapest: Tempus Public Foundation.

Kazár, K. (2014). A PLS-útelemzés és alkalmazása egy márkaközösség pszichológiai érzetének vizsgálatára. Statisztikai Szemle, 92(1) 33-52. https://www.ksh.hu/ statszemle_archive/2014/2014_01/2014_01_033.pdf

Kéri, A., Kazár, K. \& Révész, B. (2018). Külföldi hallgatói elégedettségmérés a Szegedi Tudományegyetem Gazdaságtudományi Karán. In Józsa, L., Korcsmáros, E., \& Seres Huszárik, E. (Eds.), A hatékony marketing (pp. 385-395). Komárno: Selye János Egyetem.

Kéri A. (2019). Nemzetközi hallgatói motivációk, elvárások, elégedettség és lojalitás - kvalitatív longitudinális kutatás a Szegedi Tudományegyetemen mesterképzést végzett hallgatók körében. Vezetéstudomány, 50(1), 4154. https://doi.org/10.14267/VEZTUD.2019.01.04

Kőmíves, P. M. (2020). A magyar felsőoktatás nemzetköziesedése a gazdaságtudományi képzésben [Doktori értekezés]. Debreceni Egyetem, Gazdaságtudományi Kar, Debrecen. https://ea. lib.unideb.hu/dea/bitstream/handle/2437/296613/ Komives_Peter_Miklos_disszertacio_nyilvanos_ FINAL_titkositott.pdf?sequence $=1 \&$ is Allowed $=\mathrm{y}$

Lee, J-W. (2010). Online support service quality, online learning acceptance, and student satisfaction. Internet and Higher Education, 13(4), 277-283.

https://doi.org/10.1016/j.iheduc.2010.08.002

Lenton, P. (2015). Determining student satisfaction: An economic analysis of the national student survey. Economics of Education Review, 47, 118-127. https://doi.org/10.1016/j.econedurev.2015.05.001
Machado, M. L., Brites, R., Magalhaes, A. \& Sá, M. J. (2011). Satisfaction with higher education: critical data for student development. European Journal of Education, 46(3), 415-432.

https://doi.org/10.1111/j.1465-3435.2011.01489.x

Malota E. (2010). Az országimázs átalakítása a külföldi cserediákok csoportja számára. In Dely-Gray Zs., \& Árva L. (Eds.), Turizmusmarketing esettanulmányok (pp. 218-227). Budapest: Akadémiai Kiadó.

Malota E. (2016). Hallgatói véleményfelmérés 2016, Magyarország és a magyar felsőoktatás a külföldi hallgatók szerint. Budapet: Tempus Közalapítvány. https://tka.hu/docs/palyazatok/hallgatoi_ elegedettseg_tanulmanykotet.pdf

Mekic E. \& Mekic, E. (2016). Impact of higher education service quality on student satisfaction and its influence on loyalty: Focus on first cycle of studies at accredited HEIs in BH. ICESoS 2016, Proceedings, 43-56. https://www.researchgate.net/publication/308723244 IMPACT_OF_HIGHER_EDUCATION_SERVICE_QUALITY_ON_STUDENT_SATISFACTION AND_ITS_INFLUENCE_ON_LOYALTY_ FOCUS_ON_FIRST_CYCLE_OF_- STUDIES_AT ACCREDITED_HEIS_IN_BH

Mihanovic, Z., Batinic, A. B. \& Pavicic, J. (2016). The link between students' satisfaction with faculty, overall students' satisfaction with student life and student performances. Review of Innovation and Competitiveness: A Journal of Economic and Social Research, 2(1), 37-60. https://doi.org/10.32728/ric.2016.21/3

Molnár L., Molnárné K. Cs. \& Gulyásné K. R. (2017). Hallgatói klaszterek az EDUCATIO modell alapján. In Bányai E., Lányi B., \& Töröcsik M. (Eds.), Tükrözödés, társtudományok, trendek, fogyasztás (pp. 613-620). Pécs: Pécsi Tudományegyetem, Közgazdaságtudományi Kar. http://real.mtak. hu/82380/1/Molnar_Laszlo_Molnarne_Konyha_ Csilla_Gulyasne_Kerekes_Rita___Hallgatoi_klaszterek_a_EDUC̄ATIO_modell_alapjan_u.pdf

Mucsi, A., Malota, E.\& Török, A. (2019). Külföldi hallgatók motivációi és elégedettség a külföldi tanulmányi programmal. In Veres Z., Sasné Grósz A., \& Liska F. (Eds.), Ismerjük a vevőt? A vásárlás pszichológiája: Az Egyesület a Marketingoktatásért és Kutatásért XXV. Országos konferenciájának elöadásai (pp. 1213). Veszprém, Magyarország: Pannon Egyetem.

Mucsi, A., Malota, E. \& Török, A. (2020). Kulturális sokk és pozitív szájreklám - a felsőoktatásban tanuló külföldi hallgatók körében. Vezetéstudomány, 51(2), 23-31.

https://doi.org/10.14267/VEZTUD.2020.02.02

Oliver, R. L. (1999). Whence consumer loyalty? Journal of Marketing, 63, 33-44. https://doi.org/10.2307/1252099

Owlia, M. S. \& Aspinwall, E. M. (1996). A framework for the dimensions of quality in higher education. Quality Assurance in Education, 4(2), 12-20. https:// doi.org/10.1108/09684889610116012 
Papanthymou, A. \& Darra, M (2017). Quality Management in Higher Education: Review and Perspectives, Higher Education Studies, 7(3), 132-147. http://doi.org/10.5539/hes.v7n3p132

Reichheld, F. F., Markey Jr., R. G. \& Hopton, C. (2000). The loyalty effect - the relationship between loyalty and profits. European Business Journal, 12(3), 134139. https://pdfcoffee.com/the-loyalty-effect-the-relationship-between-loyalty-and-profits-pdf-free.html

Reichheld, F. F. (2003). The one number you need to grow. Harvard Business Review, 81(12), 46-54. https://doi.org/10.1007/978-3-642-20110-3_2

Ringle, C. M., Wende, S. \& Becker, J.-M. (2015). SmartPLS 3. Boenningstedt: SmartPLS GmbH. http:// www.smartpls.com 2015.08.29.

Savitha, S. \& Padmaja, P. V. (2017). Measuring service quality in higher education: application of ECSI model. International Journal of Commerce, Business and Management, 6(5), Sep-Oct 2017.

Schertzer, C. B. \& Schertzer, S. M. B. (2004). Student satisfaction and retention: A conceptual model. Journal of Marketing for Higher Education, 14(1), 7991. https://doi.org/10.1300/J050v14n01_05

Sebrek, S. S. (2020). A magyar gazdasági felsőoktatás egy nyugati doktori fokozattal rendelkező itthon oktató nézőpontjából: Kitörési pontok beazonosítása és egy lehetséges cselekvési terv. Vezetéstudomány, 51(4), 51-62. https://doi.org/10.14267/VEZTUD.2020.04.05

Shahsavar, T. \& Sudzina, F. (2017). Student satisfaction and loyalty in Denmark: Application of EPSI methodology. PLoS ONE 12 (12), e0189576. https://doi.org/10.1371/journal.pone.0189576

Surman, V., \& Szabó, T. (2020). A minőség biztosításának kihívásai a magyar felsőoktatásban. Vezetéstudomány, 51(KSZ), 101-113.

https://doi.org/10.14267/VEZTUD.2020.KSZ.09
Toarniczky, A., Juhászné Klér, A., Kun, Z., Vajda, Éva, Harmat, V., \& Komáromi, B. (2020). Fiatal oktatókutatók tapasztalatai egy magyar üzleti iskolában. Vezetéstudomány, 51(7-8), 65-76.

https://doi.org/10.14267/VEZTUD.2020.07-08.06

Tóth, Z., \& Bedzsula, B. (2021). Treating students as partners - Is it so simple?: An empirical investigation of student partnership in a business education context. Vezetéstudomány, 52(5), 38-51. https://doi.org/10.14267/VEZTUD.2021.05.04

Turkyilmaz, A., Temizer, L. \& Oztekin, A. (2018). A casual analytic approach to student satisfaction index modeling. Annals of Operations Research, 263(1-2), 565-585. https://oi.org/10.1007/s10479-016-2245-x

Wiers-Jenssen, J., Stensaker, B. \& Grogaard, J. B. (2002). Student satisfaction: towards an empirical deconstruction of the concept. Quality in Higher Education, 8(2), 183-195.

https://doi.org/10.1080/1353832022000004377

Woodruff, R., Cadotte, E. \& Jenkins, R. (1983). Modeling Consumer Satisfaction Processes Using ExperienceBased Norms. Journal of Marketing Research, 20(3), 296-304. https://doi.org/10.1177/002224378302000308

Yang, Z., Becerik-Gerber, B. \& Mino, L. (2013). A study on student perceptions of higher education classrooms: Impact of classroom attributes on student satisfaction and performance. Building Environment, 70, 171-188.

https://doi.org/10.1016/j.buildenv.2013.08.030

Yousapronpaiboon, K. (2014). SERVQUAL. Measuring Higher Education Service Quality in Thailand. Procedia - Social and Behavioral Sciences, 116, 10881095.

https://doi.org/10.1016/j.sbspro.2014.01.350 